\title{
Healing effect of the microemulsion enriched with hydroalcoholic extract of Abarema cochliacarpa (Gomes) Barneby \& J. W. Grimes (Fabaceae)
}

Antônio Santos Dias ${ }^{1}$, Clívia Rolemberg Andrade ${ }^{1}$, André Luiz Lima Meneses Santos ${ }^{1}$, Sabrina Zelice de Moraes ${ }^{1}$, Jymmys Lopes dos Santos ${ }^{1}$, Silvan Silva de Araújo ${ }^{1}$, Andrea Yu Kwan Villar Shan ${ }^{1 *}$, Jamylle Nunes de Souza Ferro ${ }^{4}$, Marcelo Cavalcante Duarte ${ }^{2}$, Emiliano de Oliveira Barreto ${ }^{4}$, Anderson Carlos Marçal ${ }^{3}$, Ricardo Luiz Cavalcante Albuquerque Júnior ${ }^{5}$, Antonio Euzebio Goulart Santana ${ }^{4}$, Brancilene Santos de Araújo ${ }^{1}$ and Charles dos Santos Estevam ${ }^{1}$

\footnotetext{
${ }^{1}$ Department of Physiology, Federal University of Sergipe, São Cristóvão, SE, 49000-100, Brazil.

${ }^{2}$ Department of Pharmacy, Federal University of Sergipe, São Cristóvão, SE, 49000-100, Brazil.

${ }^{3}$ Department of Morphology, Federal University of Sergipe, São Cristóvão, SE, 49000-100, Brazil

${ }^{4}$ Institute of Biological and Health Sciences, Federal University of Alagoas (UFAL), Maceió, AL, 57072-900, Brazil.

${ }^{5}$ Institute of Chemistry and Biotechnology, Federal University of Alagoas (UFAL), Maceió, AL, 57072-900, Brazil.

${ }^{6}$ Tiradentes University (UNIT), Aracaju, SE, 49032-490, Brazil.
}

Received 6 July, 2018; Accepted 23 August, 2018

\begin{abstract}
Abarema cochliocarpa is an endemic plant of Brazil and has been traditionally used as a popular medicine to treat various diseases and mostly as a healing agent. The aim of this study was to evaluate the healing effect of the microemulsion containing hydrometanic fraction of the inner bark (HMF) of the plant, as well as its antioxidant, antitumor and cytotoxic potential. The cytotoxicity of HMF was assessed by the viability of $\mathbf{J 7 7 4}$ macrophages cells and the antiproliferative activity in lines of human tumor cells. The antioxidant capacity of the formulation was evaluated in vitro by the ability to scavenge the DPPH and the healing effect was evaluated in Rattus novergicus in 7, 14, 21 days. The HMF significantly favored the viability of $\mathrm{J} 774$ macrophages in all tested concentrations and it was dosedependent. The antiproliferative potential of FHM against human tumor cells was not satisfactory. This formulation presented $C_{50}$ of $24.87 \pm 0.62 \mu \mathrm{g} \cdot \mathrm{mL}^{-1}$, and healing effect of 55.18 and $100 \%$ of wound retraction up to the 7 th and $21^{\text {st }}$ days of treatment, respectively. The bioactive compound of HMF isolated by HPLC was identified by ${ }^{1} \mathrm{H}$ and ${ }^{13} \mathrm{C}$ NMR and by literature data as (+)-catechin. The formulation has curative effect. It can be concluded that the phenolic compounds act in the reduction of oxidative stress and contribute to faster healing.
\end{abstract}

Key words: Antioxidant, phenolic compound, formulation, healing.

\section{INTRODUCTION}

The role of natural products in the research of new drugs in both discovery and development is significant; about $60-75 \%$ of new drugs used to treat cancer and infectious diseases were from natural origins (Newman et al., 2016). At the beginning of the 21 st century, almost $1 / 4$ of the world's best-selling drugs were obtained directly from 
natural sources or their derivatives (Balunas and Kinghorn, 2005). In 2012, the market for herbal preparations worldwide was close to US $\$ 44$ billion and the Brazilian one was between US \$350 million and US $\$ 550$ million (Brasil, 2012). The plant species Abarema cochliacarpa is endemic to Brazil, belongs to the Fabaceae family and in folk medicine is known as "Barbatimão". It is distributed in the Atlantic Forest, Caatinga and Cerrado biomes (Da Silva et al., 2010) with a wide distribution. Its inner bark is used in the form of tea and/or "garrafadas" made with white wine or cachaça to treat and cure leucorrhoea, gastritis, purulent wounds, pains, among others (Silva et al., 2009). Studies on their chemical composition have demonstrated the presence of catechins (their dimers and trimers) mainly, as well as saponins, tannins, phenols and proanthocyanidins ( $\mathrm{Da}$ Silva et al., 2010; Dias et al., 2013). Currently, studies to discover its pharmacological potential are on the rise since even it being a medicinal species used by several Brazilian communities, there is still little scientific support. In this context, it is worth emphasizing that secondary metabolites such as flavonoids, catechins, tannins, saponins, among others may present several therapeutic benefits such as antioxidant, antitumor, antimicrobial, anti-inflammatory, antiasthmatic and cicatrizant action (Simões et al., 2007).

Healing is a tissue repair process that occurs after an injury, begins after the injury and has as purpose the formation of new tissue which is divided into three subsequent phases that are juxtaposed: inflammation, formation of granulation tissue and deposition of extracellular matrix, and remodeling (Mendonça and Coutinho-Netto, 2009; Isaac et al., 2010; Ruh et al., 2013). Over the years it has deserved researchers' attention, mainly in relation to the factors that delay or difficult its mechanisms (Santos et al., 2014). The release of ROS and RNS at the lesion site may play an important role in the modulation of the inflammatory response like the stimulus for the release of cytokines, adhesion molecules and chemotactic agents, further contributing to the maintenance of inflammation and subsequent delay in tissue repair. However, plants that demonstrate antioxidant role have been widely used in the various forms of preparation, with possible anti-inflammatory activity and assistants in the healing process (Da Silva et al., 2010; Piriz et al., 2014; Ebeling et al., 2014). In this sense, new healing agents for the treatment of cutaneous wounds, especially chronic ones, of natural origin would be of great value since they may act to decrease the undesirable effects of other drugs. Thus, this work evaluates the healing potential of a low cost formulation containing the hydrometanic fraction obtained from $A$. cochliacarpa.

\section{MATERIAL AND METHODS}

Collection, plant identification and obtainment of the active fraction

The plant sample (inner bark, $5 \mathrm{~kg}$ ) was collected at morning from a native population, located in the Caípe Velho Village $\left(11^{\circ} 0^{\prime} 49^{\prime \prime} \mathrm{S}\right.$, $\left.37^{\circ} 13^{\prime} 21^{\prime \prime} \mathrm{W}\right)$, São Cristóvão, SE, Brazil. The botanical identification was performed by Dr. Ana Paula do Nascimento Prata from the Biology Department of the Federal University of Sergipe (UFS) and a specimen was deposited in the UFS Herbarium under the voucher 014639. This sample was dried in a stove with air circulation at $40^{\circ} \mathrm{C}$ and after complete dehydration, it was milled for the extraction of the active fraction (hydrometanic fraction - HMF), rich in phenolic compounds (Dias et al., 2013) and whose studies have proved their effectiveness in the wound healing process (Viera et al., 2008; Silva et al., 2010). Thus, the HMF was obtained by liquid-liquid extraction from the ethanolic extract resuspended with $40 \%(\mathrm{v} / \mathrm{v})$ methanol and successive washes with hexane, chloroform and ethyl acetate, resulting in $40.6 \%$ yield in relation to the dry matter. After its preparation, HMF was used for chemical and biological analyzes and for the preparation of the healing formulation (microemulsion with 10\% hydrometanic fraction $-10 \%$ HMFM) with a patent registered under the registration BR1020150073810.

\section{Isolation and identification of the bioactive constituent of the active fraction}

HMF (70.2 mg) was initially subjected to flash chromatography using silica gel (70-230 mesh) and AcOet:MeOH (0 to 50\%) in polarity gradient. 26 subfractions were obtained which were monitored in TLC using silica $60 \mathrm{H}$ and mobile phase buOH: acetic acid: water (65:15:20); being revealed with ceric sulfate and UV light and collected according to the similarity of the chromatographic profile, forming 4 groups. Among them, phenolic profile $\mathrm{G}-\mathrm{I}(\mathrm{4g})$ was eluted with $\mathrm{MeOH}$ in column chromatography (CC) using Sephadex (LD-20), yielding 56 fractions which were concentrated in a rotary evaporator under reduced pressure. These fractions were monitored by TLC following the same procedure described previously and assembled into 4 subgroups (sub-I, sub-II, sub-III and sub-IV) analyzed on HPLC/DAD-UV-vis from 190 to 680 $\mathrm{nm}$. Elution was on analytical $(5 \mu \mathrm{m}, 25.0 \times 0.46 \mathrm{~cm})$ Shim-pack® PREP-ODS $\mathrm{C}_{18}$ columns, by gradient $(20 \mu \mathrm{L}$, water: $0-50 \% \mathrm{MeOH})$ for $30 \mathrm{~min}$, with $1 \mathrm{~mL} \cdot \mathrm{min}^{-1}$ flow. For elution, the subgroups were vacuum filtered using nylon membranes $(2.5 \mathrm{~cm} \times 0.45 \mathrm{~cm}$ d.i) and degassed in Ultracleaner 1400. Among them, the sub-I $(67 \mathrm{mg})$ was eluted again on preparative $\mathrm{C}_{18}$ column $(5 \mu \mathrm{m}, 25.0 \times 2 \mathrm{~cm})$, but in isocratic condition $(1000 \mu \mathrm{L}$, water: acetonitrile $0.5 \%$ acetic acid, $85: 15)$, DAD-UV-vis detection at $280 \mathrm{~nm}$, flow of $5 \mathrm{~mL} \cdot \mathrm{min}^{-1}$ with the duration of $30 \mathrm{~min}$, isolating the major compound AC-HMF-1. This isolated compound was concentrated in $\mathrm{N}_{2}$ gas and analyzed by ${ }^{1} \mathrm{H}$ and ${ }^{13} \mathrm{C}$ NMR in a Bruker 400 Ultrashield apparatus operating at $400 \mathrm{MHz}$ for the ${ }^{1} \mathrm{H}$ nucleus and at $100 \mathrm{MHz}$ for ${ }^{13} \mathrm{C}$.

\section{${ }^{*}$ Corresponding author. E-mail: andreashan@ymail.com.}

Author(s) agree that this article remain permanently open access under the terms of the Creative Commons Attribution License 4.0 International License 


\section{Cell Viability of Macrophages J774}

The viability of $\mathrm{J} 774$ cells $\left(2 \times 10^{4}\right.$ cells) was assessed in triplicate after $24 \mathrm{~h}$ of continuous exposure to HMF and measured by the colorimetric assay of tetrazolium salt 3-(4,5-dimethylthiazol-2yl)-2,5diphenyl tetrazolium bromide (MTT) reduction to formazan, according to Mosmann (1983). For this, after cell adhesion in a 96well ELISA reader plate, the culture medium was replaced with 200 $\mu \mathrm{L}$ of culture medium containing the $\mathrm{FHM}$ diluted in $0.5 \% \mathrm{DMSO}$ at respective concentrations of 10,50 and $100 \mu \mathrm{g} \cdot \mathrm{mL}^{-1}$. The plates were then incubated for $24 \mathrm{~h}$. After this time, the culture medium was replaced with $200 \mu \mathrm{L}$ MTT $0.5 \mathrm{mg}_{\mathrm{mL}}{ }^{-1}$, pre-filtered on a 0.22 $\mathrm{mm}$ milipore membrane and the plates were incubated for $3 \mathrm{~h}$. After, the supernatant was carefully aspirated and $200 \mu \mathrm{L}$ of DMSO were added to each well for the solubilization of formazan. The entire contents were transferred to a new ELISA plate and read at $570 \mathrm{~nm}$, whose absorbances were normalized according to equation:

$\% \mathrm{VC}=[\mathrm{DO}$ (treated cells) $-\mathrm{DO}($ blank) / DO (control) $-\mathrm{DO}$ (blank)] $\times 100$.

\section{Antiproliferative activity}

The antiproliferative potential of HMF was verified by cytotoxicity analysis using the MTT method (Mosmann, 1983) against the following tumor cell lines: human promyelocytic leukemia (HL-60), human ovary (OVCAR-8), colon carcinoma (HCT-116) and glioblastoma (SF295), provided by the National Cancer Institute $(\mathrm{NCl})$. In a 96-well plate, the cell lines were plated at the concentration of $0.1 \times 10^{6}$ cells. $\mathrm{mL}^{-1}$ and incubated for $24 \mathrm{~h}$ in a stove with $5 \% \mathrm{CO}_{2}$ at $37^{\circ} \mathrm{C}$. Later, $50 \mu \mathrm{g} \cdot \mathrm{mL}^{-1}$ of $\mathrm{HMF}$ was added to each well and incubated for $72 \mathrm{~h}$ in a $5 \% \mathrm{CO}_{2}$ stove at $37^{\circ} \mathrm{C}$. Then, the plate was centrifuged $(15 \mathrm{xg} / 15 \mathrm{~min})$ at $4^{\circ} \mathrm{C}$ and the supernatants removed. Then $150 \mu \mathrm{L}$ of the MTT solution (0.5 $\mathrm{mg} \cdot \mathrm{mL}^{-1}$ ) was added and again incubated for $3 \mathrm{~h}$. The plate was centrifuged $(30 \mathrm{~g} / 10 \mathrm{~min})$ at $4^{\circ} \mathrm{C}$, the supernatants were discarded and the pellets resuspended in $150 \mu \mathrm{L}$ of pure sterile DMSO. For the formazan quantification by viable cells, the absorbance was read in an ELISA at $595 \mathrm{~nm}$. Doxorubicin (Glenmark Laboratories) was used as a positive control (0.003 to $\left.0.25 \mu \mathrm{g} \cdot \mathrm{mL}^{-1}\right)$. HMF was found to cause more than $75 \%$ inhibition of growth in at least one of the cell lines tested and, therefore it was tested with increasing concentrations ranging from 0.024 to $50 \mu \mathrm{g} \cdot \mathrm{mL}^{-1}$ to determine its $\mathrm{IC}_{50}$ (minimum inhibitory concentration capable of causing $50 \%$ of maximal effect) (Ribeiro et al., 2012). The analyzes were performed in triplicate and the $\mathrm{IC}_{50}$ and their respective confidence intervals $(95 \% \mathrm{Cl})$ were performed by non-linear regression.

\section{DPPH radical-scavenging activity}

The determination of the 2,2-diphenyl-1-picrylhydrazyl (DPPH) sequestering ability was done with $10 \% \mathrm{MFHM}$ and the $10 \%$ gallic acid Microemulsion (10\% GAM) according to Brand-Wiliams et al. (1995) and the consumption of this free radical was monitored by decreasing the absorbances of test solutions in different concentrations. The samples concentrations used were: $10 \%$ HMFM at $15,20,40,50$ and $60 \mu \mathrm{g} \cdot \mathrm{mL}^{-1} ; 10 \%$ GAM at $30,60,80$ and $100 \mu \mathrm{g} \cdot \mathrm{mL}^{-1}$. The absorbance measurements of the mixtures ( $0.3 \mathrm{~mL}$ of sample solution or positive control and $2.7 \mathrm{~mL}$ of DPPH stock solution at $40 \mu \mathrm{g} \cdot \mathrm{mL}^{-1}$ were made at $515 \mathrm{~nm}$ in 1,5 and 10 min and every $10 \mathrm{~min}$ until $1 \mathrm{~h}$. The mixture of methanol $(2.7 \mathrm{~mL})$ and methanol solution of the extract $(0.3 \mathrm{~mL})$ was used as blank.
From the equation of the calibration curve $(y=110.547-0.02804 a$, 0.998 ) and the absorbance values in $30 \mathrm{~min}$ for each concentration tested, the percentages of remaining DPPH (\%DPPH ${ }_{\text {REM }}$ ) were determined. The expression of the results was made by the concentration required to decrease the initial concentration of DPPH by $50 \%\left(E_{50}\right)$, by Inhibition Percentage (IP) and by the antioxidant activity index (AAI). $\mathrm{EC}_{50}$ was calculated by plotting the $\% \mathrm{DPPH}_{\mathrm{REM}}$ at 60 min opposed to the sample concentrations being expressed in $\mu \mathrm{g} \cdot \mathrm{mL}^{-1} \pm$ standard deviation. The IP was calculated with de $60 \mu \mathrm{g} \cdot \mathrm{mL}^{-1}$ at $30 \mathrm{~min}$. The AAl was calculated according to Scherer and Godoy (2009) in which $\mathrm{AAI}=\% \mathrm{DPPH}_{\mathrm{REM}}$ (end)/EC $\mathrm{E}_{50}$ being considered unsatisfactory $\mathrm{AAI}<0.5$, moderate with $0.5<\mathrm{AAl}$ $<1.0$, strong with $1.0<\mathrm{AAI}<2.0$ and very strong with $\mathrm{AAI}>2.0$.

\section{Healing activity}

The method was performed according to Martins et al. (2006) and Carvalho et al. (2009) with modifications and the tests described were approved by the Animal Research Ethics Committee of the Federal University of Sergipe (CEPA/UFS) under protocol 57/2012. The animals, Rattus norvegicus Wistar line (3.5 months, 200-300 g) were randomly selected, housed in cages at $22 \pm 3^{\circ} \mathrm{C}$, with $12 \mathrm{~h} / 12$ $\mathrm{h}$ cycle, free access to food (Labina ${ }^{\circledR}$ ) and water ad libitum. They were divided into 3 groups: (i) No treatment Group (NTG, $n=15$ ); (ii) Vehicle Group (VG, $n=15$ ) treated with $100 \mu \mathrm{L}$ of the formulation in the absence of MHF, and; (iii) $10 \%$ hydrometanic fraction microemulsion group (10\% HMFMG, $n=15)$ treated with $100 \mu \mathrm{L}$ of the microemulsion produced from the $10 \%$ hydrometanic fraction. Each group was subdivided into 3 subgroups $(n=15)$ according to the date of the sacrifice period: 7,14 and 21 days after surgery. The animals were anesthetized intramuscularly with thiopental at a dose of $50 \mathrm{mg} \cdot \mathrm{kg}^{-1}$ and wound formation was performed by means of a $0.8 \mathrm{~mm}$ diameter punch after the application of povidine $1 \%$ for local asepsis. The measurement of the area of the wound was done through a digital caliper and the formulation corresponding to each tested group was applied except NTG. At the end of the surgical procedure, the animals were housed in their cages and monitored for anesthetic recovery, as well as normalization of the respiratory rate and the beginning of the active search for water and food. The formulations were applied daily and the animals were examined for their mobility in the open field, presence or absence of secretions, crusts or necroses. On days 7, 14 and 21, animals were weighed, anesthetized with ether, euthanized by decapitation and the wounds measured by digital caliper. The wounds were measured on days 0 (immediately after surgery), 7, 14 and 21 postoperative (immediately after euthanasia) and the area of the wounds was calculated by the equation of Prata et al. (1998): $A=$ m.R.r, where $A$ is the area $\left(\mathrm{cm}^{2}\right)$; "R", the major radius and " $r$ ", the minor radius. The degree of contraction, expressed as percentage, was measured by the equation proposed by Ramsey et al. (1995): \% of wound contraction= WO-Wi / WO x 100 , in which $\mathrm{W} 0=$ initial wound area on day 0 and $\mathrm{Wi}=$ area of the wound on the day of its excision and the results of area and contraction of the wounds were expressed as mean \pm standard deviation, submitted to analysis of variance and tested by Tukey ( $p$ $<5)$. The animals were placed in plastic bags for infecting material, frozen in an appropriate freezer and collected through the collection of biological waste by the institution.

\section{Microscopic wounds analysis}

The surgical specimens obtained from NTG, VG and 10\% GMFHM were submitted to $10 \mu \mathrm{m}$ thick sections in cryostat, and then placed on glass slides and stained by the hematoxylin-eosin method (H-E) 


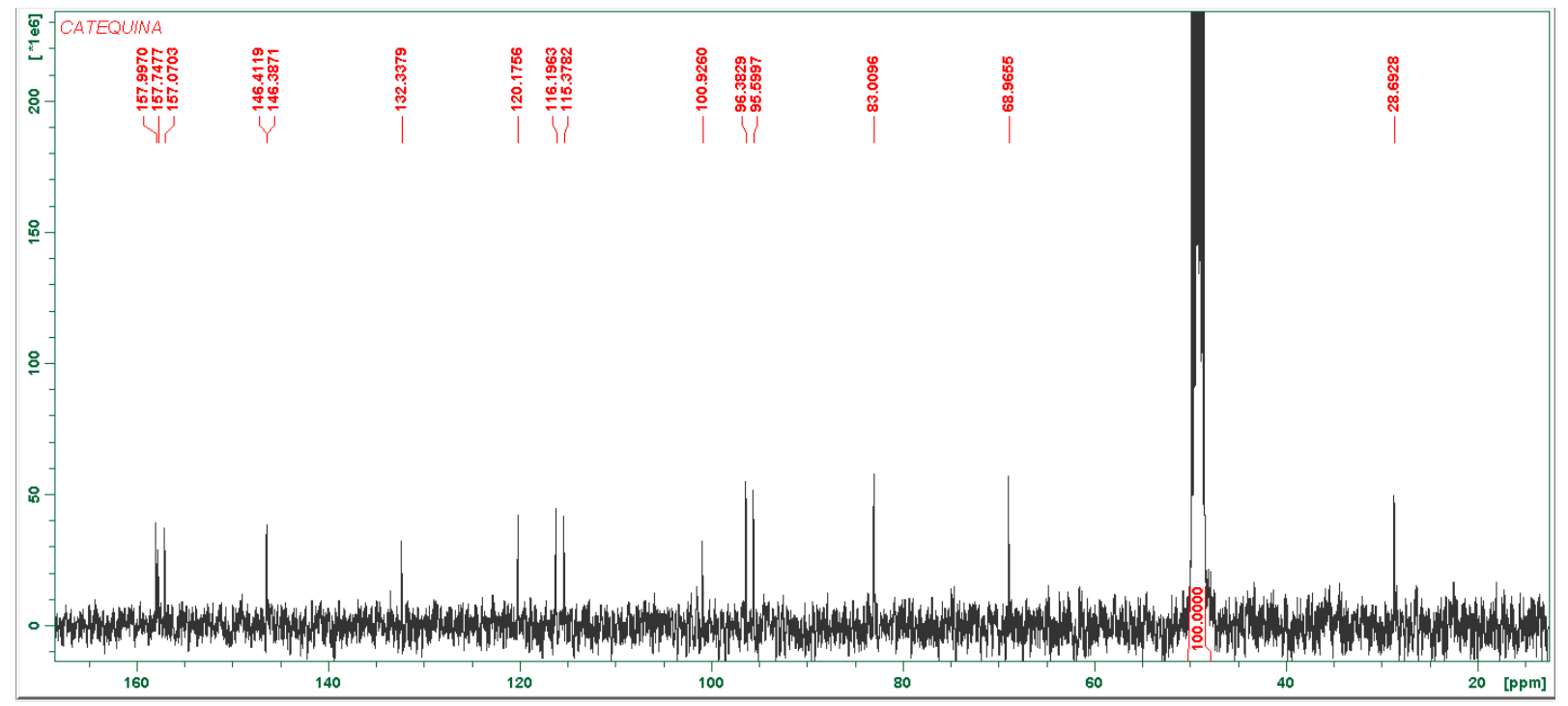

Figure 1. ${ }^{13} \mathrm{C}$ NMR spectrum (100 MHz, $\mathrm{CD}_{3} \mathrm{OD}$ ) of bioactive compound AC-FHM-1, of inner bark hydrometanic fraction A. cochliacarpa.

proposed by Luna (1968), for later microscopic observation of their respective granulation areas. The Sirius red staining method was also used for descriptive analysis of collagen deposition (Sweat et al., 1964) in which sections cut and stained were analyzed under polarized light. Collagen was classified as type I or III according to the birefringence presented, according to the morphological aspect of its fibers (striated or wavy, thin or thick, short or long) and arrangement of the bundles (reticular, interlaced or parallel).

\section{Determination of total sulfhydrides (SH)}

SH quantification was done according to Faure and Lafond (1995) in which aliquots of $200 \mu \mathrm{L}$ of blood plasma were mixed with $800 \mu \mathrm{L}$ of Tris-EDTA, pH 8,2. Thereafter, the first reading $(A)$ was carried out at $412 \mathrm{~nm}$. After the reading, the samples were transferred into test tubes and mixed in $20 \mu \mathrm{l}$ of DNTB [10 mM 5,5-dithiobis (2nitrobenzoic)] diluted in methanol $\left(4 \mathrm{mg} \cdot \mathrm{mL}^{-1}\right)$ and left to rest in the dark for $15 \mathrm{~min}$. At the end of this time, the absorbance (A2) was measured for the second reading. The $\mathrm{SH}$ concentration was calculated according to the equation: (A2 - A1) - B x $1.57 \mathrm{mM} \times$ 1000.

\section{RESULTS AND DISCUSSION}

\section{Isolation and identification of the majority constituent of the active fraction}

In the analytical condition, the HMF chromatogram showed a major peak (AC-HMF-1) in the TR of $12.2 \mathrm{~min}$ and UV-Vis spectrum with band II at maximum absorption between 240-280 $\mathrm{nm}$ and I band between 300-550 nm, characteristic of flavonoid (Ugaz, 1994). This bioactive constituent was isolated on preparative HPLC $(37 \mathrm{mg})$ and its melting range was determined at 170 to $175^{\circ} \mathrm{C}$.
The ${ }^{13} \mathrm{C}$ NMR spectrum $(100 \mathrm{mHz})$ showed characteristic signals for the basic structure of a flavonoid (Figure 1$): \delta$ 157.9 (C-7), $\delta 157.7$ (C-9), $\delta 157.0$ (C-5), $\delta 146.4$ (C-3'), $\delta 132.3\left(\mathrm{C}^{\prime} 1^{\prime}\right), \delta 120.1$ (C-6'), $\delta 116.1$ (C-5'), $\delta 115.3$ (C2'), $\delta 100.9$ (C-10), $\delta 96.3$ (C-6), $\delta 95.5$ (C-8), $\delta 83.0$ (C-2), $\delta 68.9$ (C-3), $\delta 28.6$ (C-4). The ${ }^{1} \mathrm{H}$ NMR spectrum (400 $\mathrm{mHz})$ of the substance showed $\delta 6.83(\mathrm{~d}, \mathrm{~J}=1.8 \mathrm{~Hz}, \mathrm{H}$ 2'); $\delta 6.76\left(\mathrm{~d}, \mathrm{~J}=8.1 \mathrm{~Hz}, \mathrm{H}-5^{\prime}\right.$ ), $\delta 6.71$ (dd, $\mathrm{J}=8.1$ e 1.8 Hz, H-6'), $\delta 5.93$ (d, J = 2.2 Hz, H-6), $85.85(\mathrm{~d}, \mathrm{~J}=2.2 \mathrm{~Hz}$, $\mathrm{H}-8), \delta 4.57(\mathrm{~d}, \mathrm{~J}=7.5 \mathrm{~Hz}, \mathrm{H}-2), \delta 3.97(\mathrm{~m}, \mathrm{H}-3), \delta 2.85$ (dd, $\mathrm{J}=16.1$ e $5.5 \mathrm{~Hz}, \mathrm{H}-4 \alpha), \delta 2.51$ (dd, $\mathrm{J}=16.1$ e $8.2 \mathrm{~Hz}, \mathrm{H}-$ 4ß) (Figure 2). The ${ }^{1} \mathrm{H}$ and ${ }^{13} \mathrm{C}$ NMR signals showed chemical shifts of signals identical to those reported by Lôbo et al. (2008) as + (-) catechin (Figure 3). Thus, by the data shown above and in comparison, with the literature data it is concluded that AC-HMF-1, the major constituent of HMF is the same compound already identified by Sánchez-Fidalgo et al. (2013) in the specie. Although $(+)$ - catechin is the major compound of this formulation and has an anti-inflammatory effect, studies have reported that such a substance is also an inhibitor of TGF-beta that is closely related to the process of wound contraction. In this sense, new studies are suggested only with the pure substance, since other components of the formulation probably act in the healing process.

\section{Cytotoxicity in J774 Macrophages}

HMF significantly favored the viability of $\mathrm{J} 774$ macrophages at all concentrations tested (10,50 and 100 


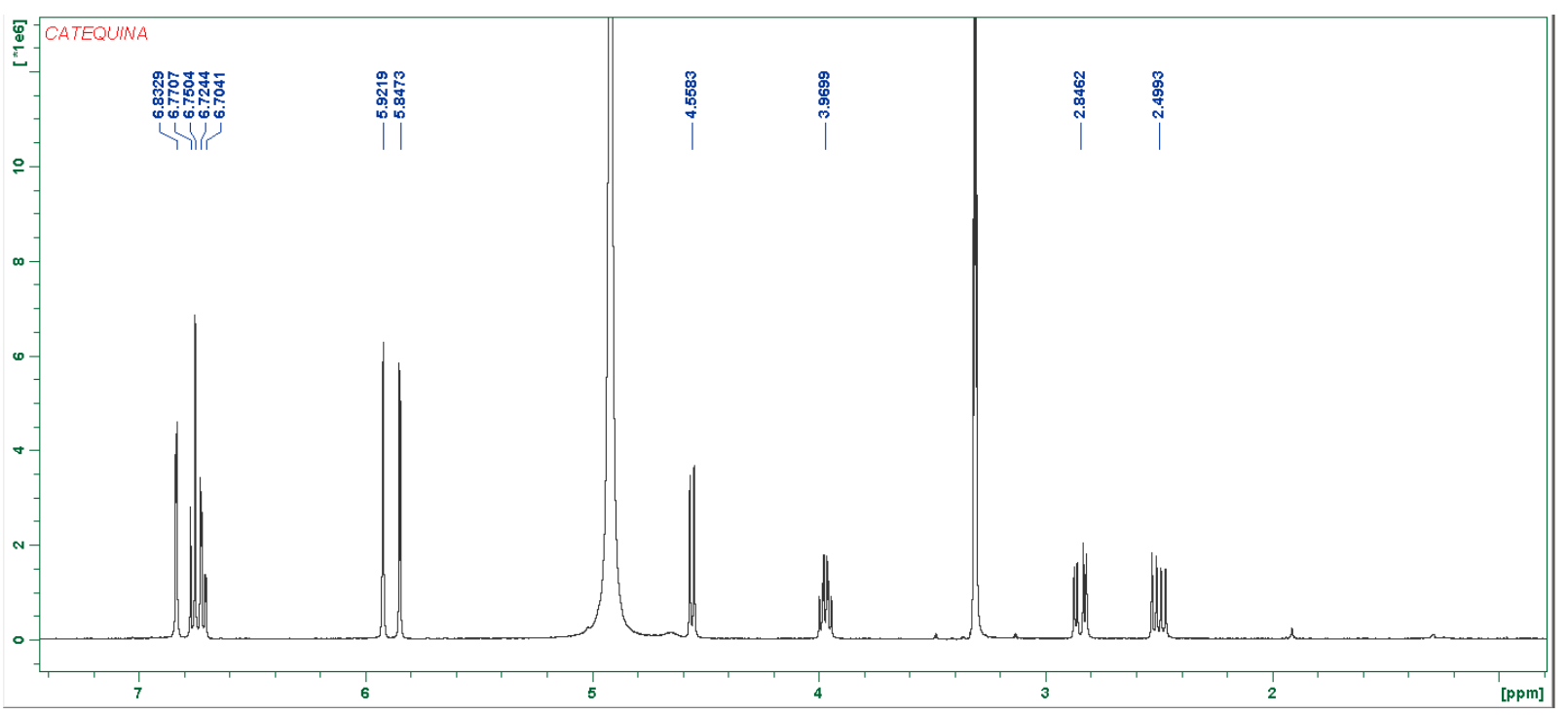

Figure 2. ${ }^{1} \mathrm{H}$ NMR spectrum $\left(400 \mathrm{MHz}, \mathrm{CD}_{3} \mathrm{OD}\right)$ of bioactive compound $\mathrm{AC}-\mathrm{FHM}-1$, of inner bark hydrometanic fraction A. cochliacarpa.

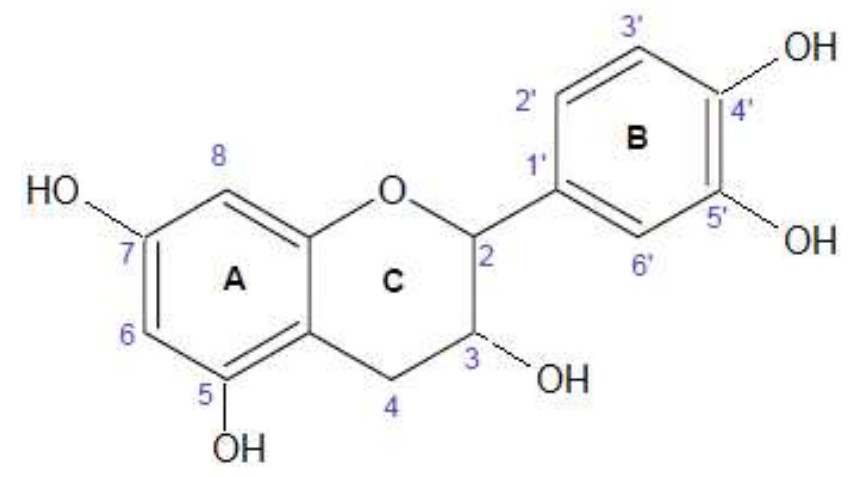

Figure 3. Catechin - bioactive compound in the inner bark hydrometanic fraction of $A$. cochliacarpa.

$\left.\mu \mathrm{g} \cdot \mathrm{mL}^{-1}\right) \quad(\rho<0.05)$ when compared to untreated cells (negative control) showing concentration-dependent behavior (Figure 4). According to Ribeiro et al. (2012), even showing a reduction was not equal to or greater than $75 \%$, from which the plant extract can be considered cytotoxic. On the other hand, for Neri-Numa et al. (2014), an extract that inhibits more than $50 \%$ of cell growth and exhibits concentration-dependent behavior is antiproliferative. The literature warns that this plant species has toxicity, however, such studies used very high concentrations and/or doses in comparison with the data from this study. In this context, Oliveira et al. (2013) demonstrated that $A$. cochliacarpa bark extracts caused hepatotoxicity in mice at concentrations of 125 to 1000 $m g \cdot \mathrm{L}^{-1}$, higher than in this study. However, Lima et al. (2014) concluded that the ethanolic extract of Pithecellobium cochliocarpum, synonym of $A$. cochliacarpa, was a toxic agent in the in vitro tests against Artemiasalina, as well as in pre-clinical tests (acute) by intraperitoneal route. In this route, doses ranged from 160 (maximum dose free of mortality) to $414.72 \mathrm{mg} \cdot \mathrm{Kg}^{-1}$ (minimum dose capable of leading to $100 \%$ death of the animals). However, when orally administered, it showed low toxicity; the doses used ranged from 1 to $5 \mathrm{~g} \cdot \mathrm{kg}^{-1}$. Thus, exposure conditions, administered or absorbed dose, time and frequency of exposure and routes of administration are variables that should be considered. 


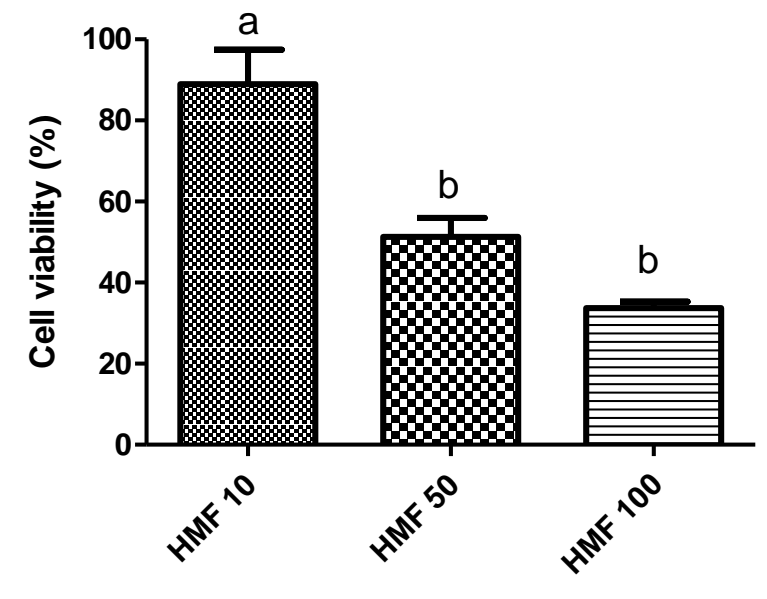

Samples $\left(\mu \mathrm{g} \cdot \mathrm{mL}^{-1}\right)$

Figure 4. Effect of inner bark hydrometanic fraction $A$. cochliacarpa on viability of $\mathrm{J} 774$ macrophages using the 3-(4,5-dimethylthiazol-2-yl)-2-5-diphenyltetrazolium bromide assay, MTT.

\section{Antiproliferative activity}

The antiproliferative potential of HMF against four human tumor cell lines, was not satisfactory for all tested strains without acceptable and compatible results with what is established by the National Cancer Institute of the United States (NCl, USA). According to this institute, the $I_{50}$ limit value for extracts considered active as or for anticancer agent should be $\leq 30 \mu \mathrm{g} \cdot \mathrm{mL}^{-1}$ (Buriol et al., 2009; Ribeiro et al., 2012). Such concentrations, from a pharmacological point of view, are more feasible for potential clinical application (Rosa et al., 2014). In addition, HMF was not able to inhibit $75 \%$ survival of the cancer cell lines used, so their $\mathrm{IC}_{50}$ were not determined.

\section{Antioxidant activity}

The antioxidant effect of $10 \%$ MHMF, produced for wound treatment, was more effective than that used as a positive control (10\% GAM) differing significantly $(\rho<$ 0.05) (Table 1). However, when comparing the antioxidant action of this formulation with the antioxidant effect of unincorporated HMF, there is a significant difference when comparing them both, $4.06 \pm 1.09$ (Dias et al., 2013) which allows to extrapolate that in 6 times for this formulation to reach the same $\mathrm{EC}_{50}$. However, this result does not eliminate the effect of the $10 \%$ MFHM, since the AAl shows that the formulation had strong antioxidant activity, which was not observed with $10 \%$ GAM, whose potential was moderate.

Still, compared to the others $\mathrm{EC}_{50}$ observed in the literature for extracts of plants considered good antioxidants, it is lower, for example the one observed in the extract of Acacia caesia (L.), whose $\mathrm{EC}_{50}$ was approximately $109 \mu \mathrm{g} \cdot \mathrm{mL}^{-1}$, 4.5 times greater than $10 \%$ MFHM (Thambiraj and Paulsamy, 2012). The same behavior was observed with methanolic extracts from the leaves and bark of Goniothalamus velutinus (Airy Shaw), with $\mathrm{EC}_{50}$ of 155.32 and $203.96 \mu \mathrm{g} \cdot \mathrm{mL}^{-1}$, respectively (Iqbal et al., 2015). It is worth mentioning that, researches carried out in different databases, showed only one study with nanostructured formulation and the same biological purpose, but based on silicone, to which trans-resveratrol was incorporated and whose antioxidant potential was unsatisfactory, inhibiting $19.85 \%$ of the $\mathrm{DPPH}^{\circ}$. In this sense, both $10 \%$ MHMF and 10\% GAM acted in the fight against the DPPH free radical action, presenting percentage of inhibition of 93.43 and $61.37 \%$, respectively (Table 1 ).

\section{Healing activity \\ Index of Clinical Wound Retraction (CWR) and area of granulation}

According to Figure 5,both 10\% HMFMG and VG showed improvement in wound healing at 7 days of treatment, being equal to each other $(\rho<0.05)$ and differing only in 
Table 1. Antioxidant potential against the free radical 2,2-diphenyl-1-picrylhydrazyl of the microemulsion formulations of the $10 \%$ hydrometanic fraction of $A$. cochliacarpa and $10 \%$ gallic acid.

\begin{tabular}{lccc}
\hline \multirow{2}{*}{ Sample } & \multicolumn{3}{c}{ Analysis parameters } \\
\cline { 2 - 4 } & $\mathbf{E C}_{50}$ & AAl & IP (\%) \\
\hline $10 \%$ hydrometanicfraction microemulsion & $24.87 \pm 0.62 \mathrm{a}$ & 1.60 & 93.43 \\
$10 \%$ gallic acid microemulsion & $57.36 \pm 0.45 \mathrm{~b}$ & 0.7 & 61.37 \\
\hline
\end{tabular}

$\mathrm{EC}_{50}$, Efficient concentration to inhibit $50 \%$ of the free radical; AAI, Antioxidant activity index; IP, Inhibition Percent. The IP was calculated based after $30 \mathrm{~min}$ and concentration of $60 \mu \mathrm{g} \cdot \mathrm{mL}^{-1}$. Statistical differences were determined by the T test $(\rho<0.05)$.

relation to NTG. Wound contraction is closely related to myofibroblastic differentiation which is a phenotypic alteration suffered by fibroblasts that acquire contractile phenotype in response to TGF- $\beta$, and cytokine released by monuclear leukocytes (lymphocytes and macrophages/histiocytes) in the injured area (Thannickal et al., 2003). In this sense, the CWR and 10\% HMFMG were the same, probably due to the presence of oleic acid in the base formulation, since fatty acids stimulate the synthesis of TGF- $\beta$ and induce the expression of contractile proteins, such as $\alpha$-actin of smooth muscle, in fibroblasts, differentiating them in myofibroblasts (Mishra and Simonson, 2008; Santos et al., 2014). In fact, several studies have highlighted that unsaturated fatty acids, including the oleic used in this formulation, act in this process by aiding tissue repair (Cardoso et al., 2011). Therefore, the similar behavior may suggest the low effectiveness of HMF because the compounds present did not act synergistically with oleic acid for this purpose, although there is a tendency. However, when the analysis of the granulation area is observed, it can be seen that at 7 days, the lowest area obtained was in $10 \%$ HMFMG, while the largest was VG. Namely, the granulation area or tissue is the point of reference for tissue repair. Its histological characteristic consists of the presence of new and small blood vessels, as well as in the proliferation of fibroblasts. Its size depends on the defect in the tissue created by the wound and the intensity of the inflammation (Santos et al., 2014). Thus, it is suggested that HMF compounds acted to reduce the inflammatory process, resulting in a smaller area of granulation. It is noteworthy that the $10 \%$ MHMF showed a strong antioxidant behavior, with a percentage of inhibition above $90 \%$ (Table 1), which reaffirms the possibility of being active in the reduction of inflammation since antioxidants have a positive correlation with the anti-inflammatory process (Oliveira et al., 2013). Furthermore, previous research by Da Silva et al. (2011) and Saturnino-Oliveira et al. (2014) showed the effectiveness of $A$. cochliacarpa in the anti-inflammatory action. At 14 days, it was observed that the three groups showed a similar pattern of CWR and granulation area ( $p$ $<0.05$ ) (Figure 5). However, regarding the observations, at 7 days of treatment, there was an increase in the percentage of retraction of the wounds and an accentuated decrease in the areas of granulation. Such behavior in this period is expected since there is a reduction in the population of myofibroblasts, certainly induced by apoptosis (Ribeiro et al., 2009). However, at 21 days, it was observed that $10 \%$ HMFMG presented $100 \%$ retraction of the wound area and lower area of granulation differing significantly $(\rho<0.05)$ from VG and NTG, which obtained equal behavior. This event is probably associated with some of the chemical constituents of $A$. cochliacarpa HMF or their synergistic action, which may have increased the local production of TGF- $\beta$, thus increasing myofibroblastic differentiation. Vieira et al. (2008) demonstrated the positive action of flavonoids in the healing process and, later, Dias et al. (2014) studying the chemical profile of $A$. cochliacarpa have claimed it to be a species rich in flavonoids. In fact, the major constituent of $10 \%$ HMFMG, the + (-) catechin is already cited as a flavonoid with anti-inflammatory potential. However, it has already been cited as a TGF- $\beta$ inhibitor, one of the growth factors closely related to the process of wound contraction, an effect not observed in this experiment. It is worth noting that at 17 days of this experiment, $10 \%$ HMFMG animals stopped receiving the topical application since their wounds were already fully contracted. Similar results were obtained in animals treated with the nanoemulsion eucalyptus oil, oil-in-water type, similar to the present study, at 16 days (Sugumar et al., 2014).

\section{Microscopic wounds analysis}

As for collagen deposition (Figure 6), the pattern observed was quite similar between groups over the experimental times, with predominance of collagen III in 7 days, depositing reticulated greenish fibers, characteristic of this type of collagen. On the 14th day, there was both the deposition of type I collagen, with golden and reddish fibers, well interlaced, as well as type III. In 21 days, it was possible to notice the resumption of collagen type III deposition in the three groups, mainly NTG and VG, in 
7 days

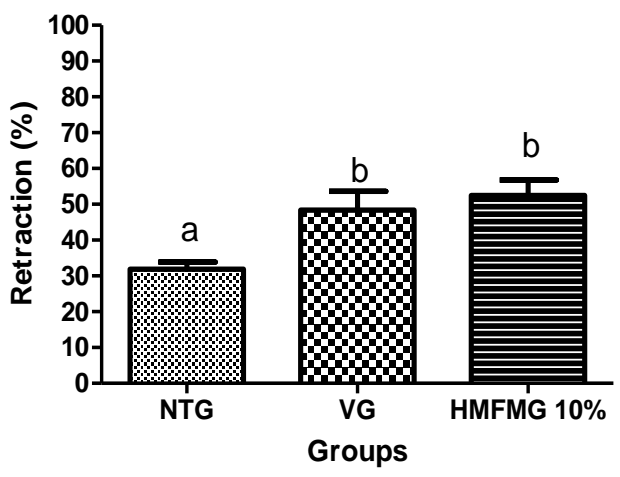

14 days

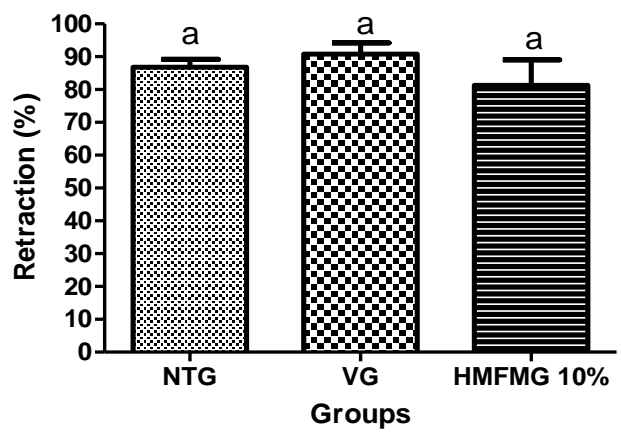

21 days

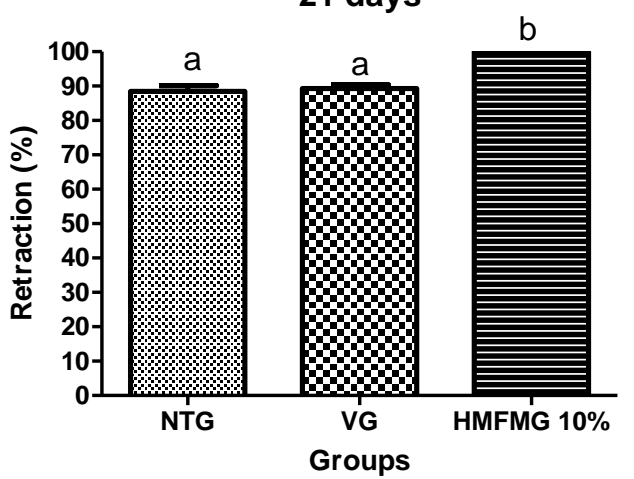

7 days

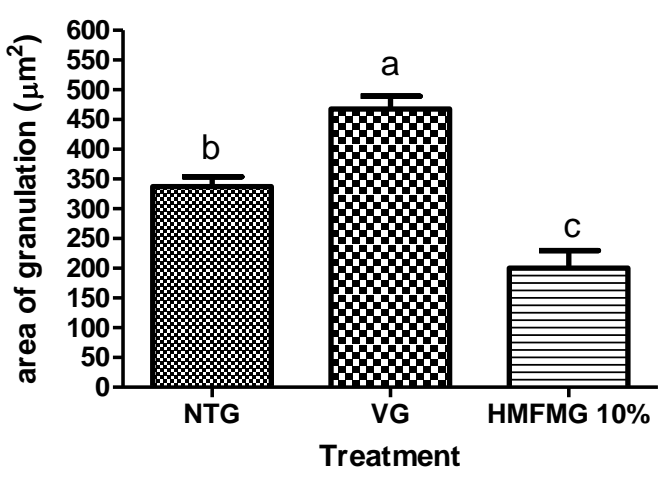

14 days

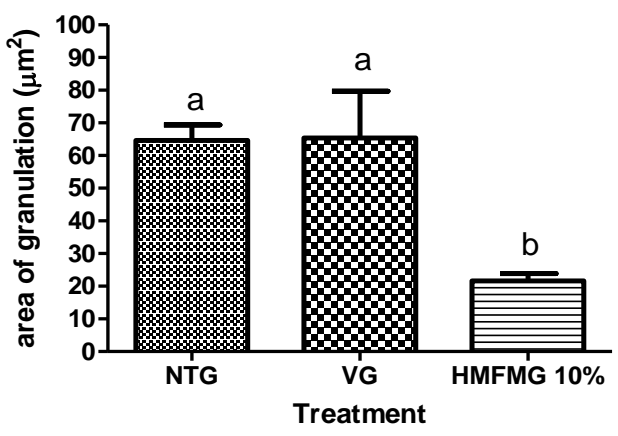

21 days

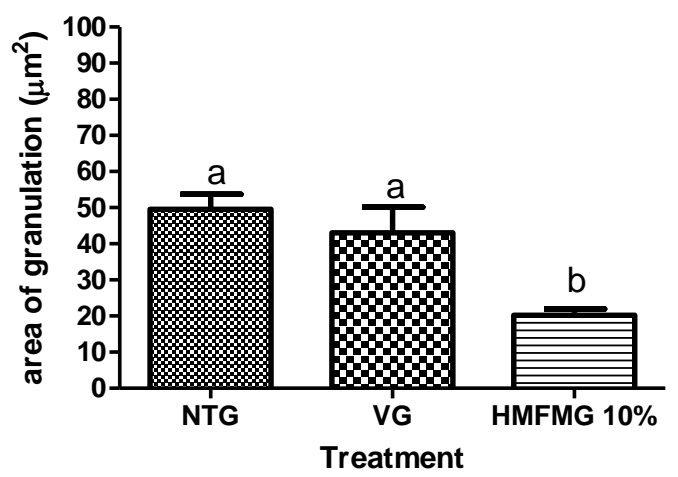

Figure 5. Index of Clinical Wound Retraction and area of granulation demonstrated by the treatment with $A$. cochliacarpa microemulsion, in open wounds of $R$. novergicus, during 7, 14 and 21 days. NTG, Group without treatment; VG, Vehicle group; 10\%HMFMG, 10\% Hydrometanic fraction microemulsion group compared by Tukey $(p<0.05)$.

detriment of type I, as observed on the 7th day. This may be associated with the remodeling process of type I collagen and the synthesis and deposition of type III collagen. This resumption of collagen III deposition at the wound site is probably due to the papillary dermis which also synthesizes it (Isaac et al., 2010). Among the three groups analyzed, in 21 days, 10\% HMFMG showed lower deposition of collagen I than the others. This fact is associated with a more accentuated repair process that should have been favored by the constituents of $A$. cochliacarpa HMF, which, as previously mentioned, caused an increase in the differentiation of myofibroblasts 

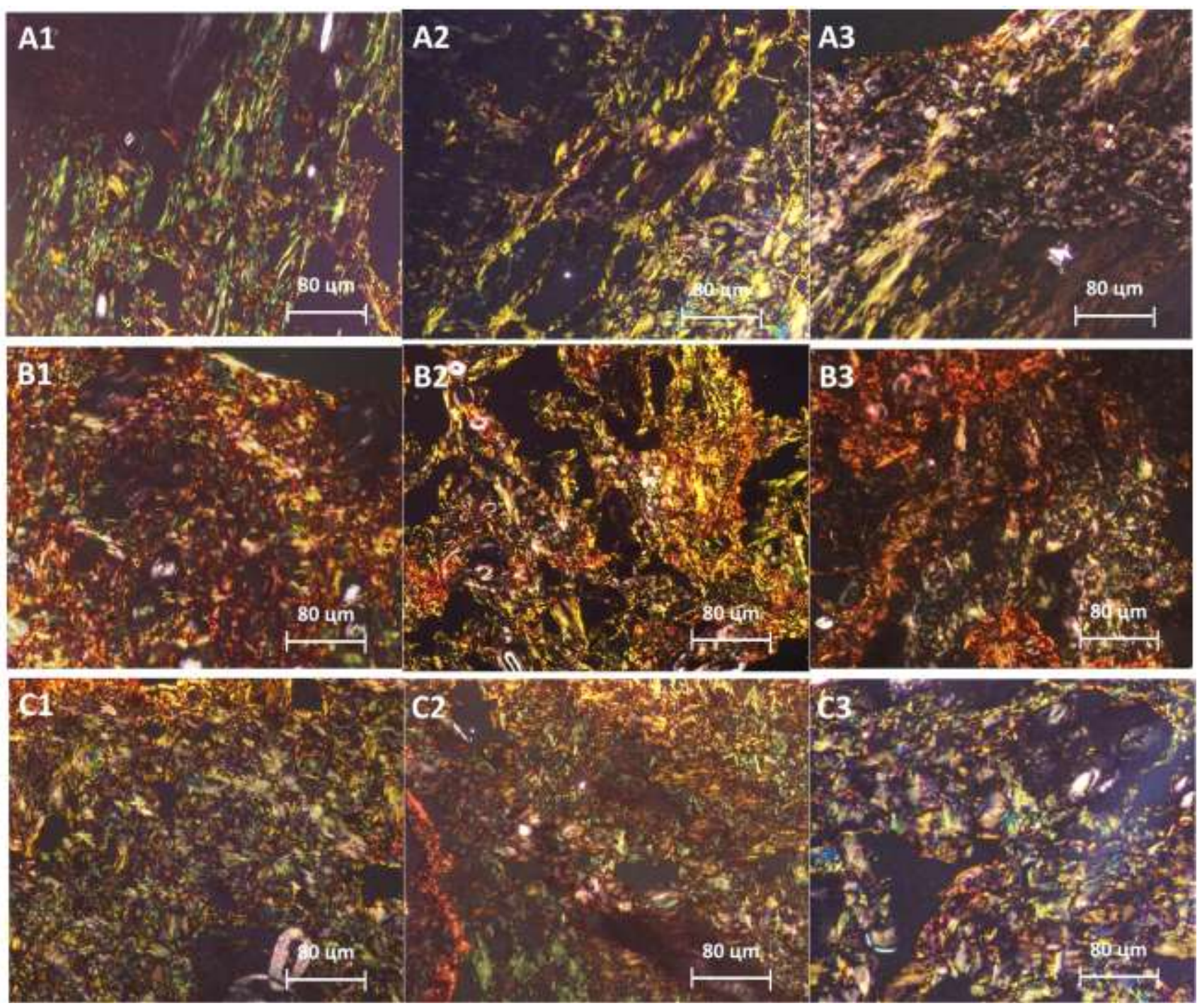

Figure 6. Collagen deposition of animals submitted to the healing activity treated with the $10 \%$ hydrometanic fraction microemulsion of the inner bark of $A$. cochliacarpa. A1, B1 and C1, Group without treatment in 7, 14 and 21 days, respectively; A2, B2 and C2, vehicle group in 7, 14 and 21 days, respectively; A3, B3 and C3, hydrometanic fraction Microemulsion of stem bark of A. cochliacarpa group coarser in 7, 14 and 21 days, respectively (Sirius Red/Polarized light - greenish birefringence: type III collagen; red-gold birefringence: type I collagen).

and accelerated the remodeling process with its successive stages of production, digestion and orientation of collagen fibrils (Hatanaka and Curi, 2007).

\section{Determination of total sulfhydriles (SH)}

According to Table 2, the concentration of $\mathrm{SH}$ on the 7th day presented a significant difference $(\rho<0.05)$ between $10 \%$ HMFMG and NTG being higher in the first, and may be associated with a higher antioxidant effect. However, on the 14th and 21st days, there was no difference between any of the groups analyzed.
Thiol groups $(\mathrm{SH})$ are structures associated with proteins and susceptible to oxidative damage. Its decrease in blood plasma is indicative of oxidative stress (Silva et al., 2014), and probably the largest area of granulation observed in both the NTG and VG groups is a result of a higher contribution of RNS inflammatory cells (phagocytes) to the wound site, thereby resulting in ROS and consequently causing depletion at SH levels. Among these species, the superoxide anion that reacts with nitric oxide peroxynitrite (ONOO-) was highlighted, whose presence in the tissues or body fluids leads to its rapid protonation, culminating, therefore, with $\mathrm{SH}$ depletion (Filippin et al., 2008; Silva et al., 2011). In contrast, the 
Table 2. Levels of sulfhydryl $(\mathrm{SH})$ in blood plasma of rats treated with $10 \%$ hydrometanic fraction microemulsion of the stem bark of $A$. cochliacarpa compared with vehicle group and group without treatment for 7, 14 and 21 days

\begin{tabular}{lccc}
\hline \multirow{2}{*}{ Sample } & \multicolumn{3}{c}{ SH (nmol.mg (n) $^{-1}$} \\
\cline { 2 - 4 } & 7thday & 14th days & 21th day \\
\hline 10\% HMFMG & $431.94 \pm 89.58^{\mathrm{a}}$ & $164.9 \pm 41.3^{\mathrm{a}}$ & $151.0 \pm 81.7^{\mathrm{a}}$ \\
VG & $337.44 \pm 66.48 \mathrm{ab}$ & $185.3 \pm 43.3^{\mathrm{a}}$ & $163.0 \pm 19.8^{\mathrm{a}}$ \\
NTG & $277.54 \pm 130.3^{\mathrm{b}}$ & $141.0 \pm 39.4^{\mathrm{a}}$ & $226.1 \pm 108.4^{\mathrm{a}}$ \\
\hline
\end{tabular}

$10 \%$ HMFMG, $10 \%$ hydrometanic fraction microemulsion group; GV, vehicle group; NTG, no treatment group. The results were represented in mean \pm SD and analyzed by Tukey $(\rho<0.05)$.

higher concentration of $\mathrm{SH}$ present in the blood plasma of $10 \%$ HMFMG animals reflects the presence of antioxidant compounds, such as flavonoids present in its composition (Dias et al., 2013). It is noteworthy that at 7 days of treatment, it was found that $10 \%$ HMFMG showed a lower area of granulation and that this result was associated with the reduction of the inflammatory process probably caused by the active compounds of HMF.

\section{Conclusion}

The microemulsion elaborated with the hydrometanic fraction obtained from the inner bark of $A$. cochliacarpa at $10 \%$, has antioxidant and healing potential from its constituents, which need to be better explored separately for the knowledge of the biological effectiveness of each one.

\section{CONFLICT OF INTERESTS}

The authors have not declared any conflict of interests.

\section{REFERENCES}

Balunas MJ, Kinghorn AD (2005). Drug discovery from medicinal plants. Life Science 78:431-441. https://doi.org/10.1016/j.lfs.2005.09.012

Brand-Williams W, Cuvelier ME, Bers ETC (1995). Use of a free radical method to evaluate antioxidant activity. LWT- Food Science and Technology 28: 25-30. https://doi.org/10.1016/S0023-6438(95)800085

Buriol L, Finger D, Schimidt EM, Santos JMT, Rosa MR, Quináia SP, Torres YR (2009). Composição química e atividade biológica de extrato oleoso própolis: uma alternativa ao extrato etanólico. Química Nova 32:296-302. https://dx.doi.org/10.1590/S010040422009000200006

Cardoso CR, Favoreto Júnior S, Oliveira LL, Vancim JO, Barban GB, Ferraz DB, Silva JS (2011). Oleic acid modulation of the imune response in wound healing: a new approach for skin repair. Immunobiology 216:409-415.https://doi: 10.1016/j.imbio.2010.06.007

Carvalho FC, Sarmento VHV, Chiavacci LA, Barbi MS, Gremião MPD
(2009). Development and in vitro evaluation of surfactante systems for controlled release of zidovudine. Journal of Pharmaceutical Sciences 99:2367-2374. https://doi.org/10.1002/jps.22005

Da Silva MS, Almeida ACA, Faria FM, Luiz-Ferreira A, Silva MA, Vilegas W, Pellizon CH, Brito ARMS (2010). Abarema cochliacarpos: Gastroprotective and ulcer-healing activities. Journal Ethnopharmacology 132(1):134-142. https://doi.org/10.1016/j.jep.2010.08.001

Da Silva MS, Sánchez-Fidalgo S, Cárdeno A, Talero E, Da Silva MA, Vilega W, Brito ARMS, DeLa Lastra CA (2011). Chronic administration of Abarema cochliacarpos attenuates colonic inflammation in rats. Revista Brasileira de Farmacognosia 21(4): 680690. https://dx.doi.org/10.1590/S0102-695X2011005000122

Dias AS, Lima ACB, Santos ALML, Rabelo TK, Serafini MR, Andrade CR, Fernandes XA, Moreira JCF, Gelain DP, Estevam CS, Araujo BS (2013). Redox properties of Abarema cochliacarpos (Gomes) Barneby and Grimes (Fabaceae) stem bark ethanol extract and fractions. Natural Products Research 27(16):1479-1483. https://doi.org/10.1080/14786419.2012.722083

Dias AS, Araujo SS, Araújo BS, Estevam CS (2014) Technological prospection of Abarema cochliacarpos Revista Geintec 4(5):1484 1488.

Ebeling S, Naumann K, Pollok S, Wardecki T, Vidal-y-Sy S, Nascimento JM, Boerries M, Schmidt G, Brandner JM, Merfort I (2014). From a traditional medicinal plant to a rational drug: understanding the clinically proven wound healing efficacy of birch bark extract. PloS one 9(1):e86147. https://doi.org/10.1371/journal.pone.0086147

Faure P, Lafond JL (1995). Analysis of Free Radicals in Biological Systems. 1st ed. Birkhäuser; Basel, Switzerland. Measurement of plasma sulfhydryl and carbonyl groups as a possible indicator of protein oxidation pp. 237-248.

Filippin LI, Vercelino R, Marroni NP, Xavier RM (2008). Influência de processos redox na resposta inflamatória da artrite reumatoide. Revista Brasileira de Reumatologia 48:1724. https://dx.doi.org/10.1590/S0482-50042008000100005.

Hatanaka E, Curi R (2007). Ácidos graxos e cicatrização: uma revisão. Revista Brasileira de Farmácia 88(2):53-58.

Iqbal E, Salim KA, Lim LBL (2015). Phytochemical screening, total phenolics and antioxidant activities of bark and leaf extracts of Goniothalamus velutinus (Airy Shaw) from Brunei Darussalam. Journal of King Saud University Science 27(3):224-232. https://doi.org/10.1016/j.jksus.2015.02.003

Isaac C, Ladeira PRS, Rêgo FMP, Aldunate JCB, Ferreira MC (2010). Processo de cura das feridas: cicatrização fisiológica. Revista de Medicina 89:125-131. https://doi.org/10.11606/issn.16799836.v89i3/4p125-131

Lima CMP, Soares RPF, Bastos IVGA, Grangeiro ARS, Gurgel APAD, Silva ACP, Silva JG, Oliveira RAG, Souza IA (2014). Evaluation of acute toxicity of the Pithecellobium cochliocarpum (Gomez) Macbr bark extract. Revista Brasileira de Plantas Medicinais 16(4):832-838. 
https://dx.doi.org/10.1590/1983-084X/10_118

Lôbo LT, Castro KCF, Arruda MSP, Silva MN, Arruda AC, Müller AH, Arruda GMSP, Santos AS, Souza Filho APS (2008). Allelopathic potential catechins of the Tachigali myrmecophyla (Leguminosae).Química Nova 31(3):493497. http://dx.doi.org/10.1590/S0100-40422008000300005

Martins NLP, Malafaia O, Ribas-Filho JM, Heibel M, Baldez RN, Vasconcelos PRL, Moreira H, Mazza M, Nassif PAN, Wallbach TZ (2006). Análise comparativa da cicatrização da pele com o uso intraperitoneal de extrato aquoso de Orbignya phalerata (Babaçu). Acta Cirurgica Brasileira 21(3):66-75. https://dx.doi.org/10.1590/S0102-86502006000900010.

Mendonça RJ, Coutinho-Netto J (2009). Aspectos celulares da cicatrização. Anais Brasileiros de Dermatologia 84(3):257262. https://dx.doi.org/10.1590/S0365-05962009000300007

Mishra R, Simonson MS (2008). Oleate induce a myofibroblast-like phenotype in mesangial cells. Arteriosclerosis, Thrombosis, and Vascular Biology https://doi.org/10.1161/ATVBAHA.107.157339

Mosmann T (1983). Rapid colorimetric assay for cellular growth and survival: application to proliferation and cytotoxicity assays. Journal of Immunology Methods 65:55-63. https://doi.org/10.1016/00221759(83)90303-4

Neri-Numa IA, Carvalho-Silva LB, Ferreira JEM, Machado ART, Malta LG, Ruiz ALG, Carvalho JE, Pastore GM (2014). Preliminary evaluation of antioxidant, antiproliferative and antimutagenic activities of pitomba (Talisiaesculenta). LWT - Food Science and Technology 59(2):1233-1238. https://doi.org/10.1016/j.Iwt.2014.06.034

Newman DJ, Cragg GM, Snader KM (2016). Natural products as sources of drugs over the period 1981-2014. Journal of Natural Products 79(3):629-61. https://doi.org/10.1021/acs.jnatprod.5b01055

Oliveira RF, Antunes CGC, Santos GKM, Oliveira CS, Silva PRC, Rocha EM, Fernandez LG, Trindade RC (2013). Use of Abarema cochliacarpos (Gomes) Barneby \& J. W. Grimes on the skin burn treatment of wistar Rattus novergicus. Revista Brasileira de Farmacognosia 94:302-306.

Piriz MA, Lima CAB, Jardim VMR, Mesquita MK, Souza ADZ, Heck RM (2014). Plantas medicinais no processo de cicatrização de feridas: uma revisão de literatura. Revista Brasileira de Plantas Medicinais 16(3):628-636. http://dx.doi.org/10.1590/1983-084X/12_178.

Prata MB, Haddad CM, Goldenberg S, Simões MJ, Moura LAR, Trabulsi LR (1988). Uso tópico do açúcar em ferida cutânea. Estudo experimental em ratos. Acta Cirurgica Brasileira 3:43-48.

Ramsey DT, Pope ER, Wagner-Mann C, Berg JN, Swain SF (1995). Effects of three occlusive dressing materials on healing of full thickness skin wounds in dogs. American Journal of Veterinary Research 56:941-949.

Ribeiro MAG, Albuquerque-Júnior RLC, Ramalho LMP, Pinheiro, ALB, Bonjardim LR, Cunha SS (2009). Immunohistochemical assesment of myofibroblasts and lymfhoid cells duryng wound healing in rats subjected to laser photobiomodulation at $660 \mathrm{~nm}$. Photomedicine and Laser Surgery 27(1):49-55. https://doi.org/10.1089/pho.2007.2215

Ribeiro SS, De Jesus AM, Dos Anjos CS, Da Silva TB, Santos ADC, De Jesus JR, Andrade MS, Sampaio TS, Gomes WF, Alves PB, Carvalho AA, Pessoa C, De Moraes MO, Pinheiro MLB, Prata APN, Blank AF, Silva-Mann R, Moraes VRS, Costa EV, Nogueira PCL, Bezerra DP (2012). Evaluation of the cytotoxic activity of some brazilian medicinal plants. Planta Medica 78:1601-1606. http://dx.doi.org/10.1055/s-0032-1315043

Rosa AS, Bandeira LG, Monte-Alto-Costa A, Romana-Souza B (2014). Supplementation with olive oil, but not fish, improves cutaneous wound healing in stressed mice. Wound Repair and Regeneration 22(4):537-547. https://doi.org/10.1111/wrr.12191

Ruh AC, Fernandes D, Artoni RF, Favero GM (2013). Inflamação: entre a regeneração e a cicatrização. Ciências Biológicas e da Saúde 19(1):11-19.https://dx.doi.org/10.5212/publicatio\%20uepg.v19i1.5565

Sánchez-Fidalgo S, Da Silva MS, Cárdeno A, Aparicio-Soto $M$, Salvador MJ, Frankland-Sawaya ACH, De La Lastra CA (2013). Abarema cochliacarpos reduces LPS-induced inflammatory response in murine peritoneal macrophages regulating ROS-MAPK signal pathway. Journal of Ethnopharmacology 149(1):140-147. https://doi.org/10.1016/j.jep.2013.06.013

Santos JAA, Sousa MFAM, Silva ELV, Aguiar Júnior FCA (2014). Avaliação histomorfométrica do efeito do extrato de urucum (norbixina) no processo de cicatrização de feridas cutâneas em ratos. Revista Brasileira de Plantas Medicinais 16(3):637-643. http://dx.doi.org/10.1590/1983-084x/12_120.

Saturnino-Oliveira J, Santos DC, Guimarães AG, Dias AS, Tomaz MA, Monteiro-Machado M, Estevam CS, De Lucca Junior W, Maria DA, Melo PA, Araújo AAS, Santos MRV, Almeida JRGS, Oliveira RCM, Oliveira AP, Quintans-Júnior LJ (2014). Abarema cochliacarpos extract decreases the inflammatory process and skeletal muscle injury induced by Bothropsleucurus Venom. BioMed Research International 1(9). https://dx.doi.org/10.1155/2014/820761

Scherer R, Godoy HT (2009). Antioxidant activity index (AAI) by the 2,2diphenyl-1-picrylhydrazyl method. Food Chemistry 112(3):654-658. https://doi.org/10.1016/j.foodchem.2008.06.026

Silva CDC, Nascimento Junior RS, Paredes LJ, Roos TB, Almeida MB (2014) Caracterização do processo de cicatrização cutânea por segunda intenção em búfalos (Bubalus bubalis). Revista Brasileira Medicina Veterinária 36(3):301-306

Silva DC, Cerchiaro G, Honório KM (2011). Relações patofisiológicas entre estresse oxidativo e arteriosclerose. Química Nova 34:300-305. http://dx.doi.org/10.1590/S0100-40422011000200024

Silva NCB, Esquibel MA, Santos JES, De Almeida MZ, Sampaio C, Barros TF (2010). In vitro antimicrobial activity of extracts from Abarema cochliacarpos (Gomes) Barneby and Grimes. African Journal of Microbiology Research 4(15):1654-1658. http://dx.doi.org/10.1590/S0102-695X2007000200014

Silva NCB, Esquibel MA, Alves IM, Velozo ES, Almeida MZ, Santos JES, Campos-Buzz F, Meira AV, Cechinel-Filho V (2009). Antinociceptive effects of Abarema cochliacarpos (B. A. Gomes) Barneby and JW Grimes (Mimosaceae). Revista Brasileira de Farmacognosia 19(1a):46-50. http://dx.doi.org/10.1590/S0102 695X2009000100011.

Simões CMO, Schenkel EP, Gosmann G, De Mello JCP, Mentz LA, Petrovick PR (2007). Farmacognosia: da planta ao medicamento, $2^{\mathrm{a}}$ ed., Porto Alegre/Florianópolis: UFRGS/UFSC 821 p.

Sugumar S, Ghosh V, Nirmala MJ, Mukherjee A, Chandrasekaran N (2014). Ultrasonic emulsification of eucalyptus oil nanoemulsion: antibacterial activity against Staphylococcus aureus and wound healing activity in Wistar rats. Ultrasonics Sonochemistry 21(3):10441049. https://doi.org/10.1016/j.ultsonch.2013.10.021

Sweat F, Puchtler H, Rosenthal SI (1964). Sirius red F3BA as a stain for connective tissue. Archives Pathology 78:69-72.

Thambiraj J, Paulsamy S (2012). In vitro antioxidant potential of methanol extract of the medicinal plant, Acacia caesia (L.) Willd. Asian Pacific Journal Tropical Biomedicine 2(1):732-736. https://doi.org/10.1016/S2221-1691(12)60305-0

Thannickal VJ, Lee DY, White ES, Cui Z, Larios JM, Chacon R, Horowitz JC, Day RM, Thomas PE (2003). Myofibroblast differentiation by transforming growth factor- $\beta 1$ is dependente on cell adhesion and integrin signaling via focal adhesion kinase. Journal of Biology Chemistry 278(14):12384-12389. https://doi.org/10.1074/jbc.M208544200

Ugaz OL (1994). Investigación Fitoquímica: métodos en el estúdio de productos naturales. $2^{\mathrm{a}}$ ed., Pontificia Universidad Católica Del Peru: Fondo Editorial pp. 127-128.

Vieira AP, Santos NR, Borges JHS, Vicenzi MPA, Schmitz WO (2008). Ação dos flavonoides na cicatrização por segunda intenção em feridas limpas induzidas cirurgicamente em ratos Wistar. Semina: Ciênc. Biol. e da Saúde 29(1). http://dx.doi.org/10.5433/16790367.2008v29n1p65 